\title{
Ideologies and Censorship in the Discourse of Two Opinion Columns: A Critical Discourse Analysis
}

\author{
Jhon Alejandro Marín González \\ University of Guanajuato, MEXICO \\ Division of Social Sciences and Humanities
}

Received: 11 June 2021 - Accepted: 1 October 2021 - Published Online: 13 November 2021

\begin{abstract}
This article examines two opinion columns titled "Dilema Ético" (Ethical Dilemma) and "A Margarita" (To Margarita) from a Critical Discourse Analysis perspective. The relevance of the analysis of these columns is that they were written within a context of social crisis in Colombia where the political polarization has increased over the last years. The study intends to identify and analyze expressions used in the discourse of two columnists that represent opposite political ideologies and how this can enact constraints of freedom of speech. The analysis is conducted through Critical Discourse Analysis (CDA). The findings show that the columnist identified with right-wing ideologies imposed herself on the columnist aligned with left-wing ideologies, thus restrict her freedom of speech.
\end{abstract}

Keywords: critical discourse analysis, ideology, political spectrum, opinion column, freedom of speech.

\section{Introduction}

Freedom of speech has been systematically hindered in Colombia (Gómez \& Hernandez, 2008; Cañizalez, 2015), over the last decades there has been a surge in the number of TV presenters, journalists, and columnists who have been removed from traditional newspapers, magazines, radio, and television. The common topic for their removal was their opinions against the illegal armed groups, the government, some politicians, or other interests of the established institutions.

This is the way the power of politics is enacted in this context. Most of these mass media broadcasters belong to the richest people in Colombia who are aligned with the current ruling government in the country. An example of this is the resignation of the columnist Margarita Rosa de Francisco from the traditional Colombian newspaper El Tiempo. In her column entitled "Dilema Ético", she discusses the way power is articulated in Colombia and how it has contributed to the social crisis the country faces. She expresses her dilemma of opposing the government's ideas while working for an institution that is aligned with the current government's ideology. For this reason, the newspaper director, Luz Ángela Sarmiento, responds with the column, "A Margarita". Therefore, the present analysis seeks to identify and analyze expressions used in the discourse of two columnists that represent opposite political ideologies and how this can enact constraints of freedom of speech. The next section presents the literature review of the study.

(C) Authors. Terms and conditions of Creative Commons Attribution 4.0 International (CC BY 4.0) apply. Correspondence: Jhon Alejandro Marín-González, University of Guanajuato, Division of Social Sciences and Humanities, Guanajuato, MEXICO. E-mail: alejandro.marin.gonzalez@gmail.com. 
- Referring to people with money power and political power in media outlets can enact censorship.

- Being identified as an individual with leftish ideas in the Colombian context may be a cause for freedom of speech constrains.

- Opinions are minimized and treated as an insult or a slander by those ones mentioned to devalue an argument utilized by the writer.

\section{Literature review}

This section provides a broad definition of the concept and the study of ideology, and the definition of left- and right-wing in the Colombian context, and the definition of freedom of speech and self-censorship. It includes the operationalization of the concepts.

\subsection{The concept of ideology}

The concept of ideology has been discussed widely over the past years. Its ubiquitous meaning is applied to different concepts like the idea, theory, science, belief, value, and utopia (Sartori, 1991). For Gerring (1997) an ideology is "a set of idea-elements that are bound together, that belong to one another in a non-random fashion" (p. 980). Hence, ideology can have different interpretations, but it is tied to different elements that underpin such "idea". Van Dijk (1998) recognizes two domains in the definition of ideology: the cognitive and the sociocognitive. The cognitive perspective is constituted by a system of ideas, or beliefs that a certain group of people have and represent their interests. The sociocognitive domain involves the cognitive part and adds a second component. An instance of this can be found in the newspapers' opinions where the columnists views' "are usually not personal, but social, institutional, or political" (Van Dijk, 1998: 22).

Therefore, in the context of this paper, the author sees ideology as something ("an idea") shared rather than personal, and does not necessarily refer to the cultural, national, or linguistic community, but a specific group. They are not shared by all the members in a large community (at the country level, for example), but in smaller ones like people that belong to a specific political party. The ideology commonly refers to rigid, fake, and biased ideas of others. It usually addresses the idea of "we have the truth; they have ideologies" (Van Dijk, 2006: 728). In other words, an ideology is opposite of what people believe is true. Van Dijk (2006), on the other hand, states that an ideology is the "foundation of the social representations shared by a social group" (p. 729). The representations that people who belong to the high class, are different from those in the middle and low class, for example. For the analysis presented in this paper, the view of ideology proposed by Van Dijk is used. Consequently, the notion of ideology as a sociocognitive orientation is taken as the discourse of the newspaper. The next section presents the concepts of left- and right-wings ideologies.

\subsection{The left- and right-wing}

Back in 1789 during the French Revolution, in the Assemblée Nationale Constituante (National Constitutional Assembly) these concepts appeared for the first time. In the discussion of the king's Louis XVI absolute veto, the assembly was divided in two. On the right side, those who agreed to leave the power of the king stood up so that the old regime continued while, on the left side, those who believed that the power should remain in the population, thus they opposed to such regime (González \& Queirolo, 2013). However, such division can be unreliable as, within each side of the spectrum, there are several shades that distant from the extremes. 
According to Boix (1996), the left- and right-wing (social democrats and conservatives, respectively) share the goal at the macro level, the maximization of the growth rate. The left usually attempts to balance growth and equity by increasing the participation of the state in the country's economy and investing in the formation of human capital. In contrast, the right intends to reduce the public sector, the taxes, but poorly invest in the formation of human and fixed capital. In this sense, the right tends to incentive the private sector in different economic activities (transportation, finance, commerce, construction, mining, and communications, for example). The left, on the other hand, is aligned with the incentive to the public sector.

Coppedge (1997) elaborates a political party classification in the left- and right-wing axis. According to the author, the right-wing is often characterized by the traditional elite population, their discourse usually involves fascist or neofascist expressions. They are usually authoritative. The center-right-wing, apart from the support from the elites, emphasizes the cooperation between the private sector, the public order, honest governments, and priority of the economic growth over distribution. On the contrary, the center-left-wing ideas emphasize justice, equity, and social mobility while the left-wing prioritize distribution over accumulation.

Fagerholm (2016) identified two subtypes of the concept of (political) ideology: communal and particular. The first involves all the society (a type of Marxist view of the society) while the second is opposed to it and it is much more narrowed and typically identified as a delimited group, class, or movement (the diversification of ideas among the political spectrum). The following table shows a general view of the concept.

Table 1. Concept of particular ideologies

\begin{tabular}{|c|c|}
\hline $\begin{array}{l}\text { Conservative Particular } \\
\text { Ideology }\end{array}$ & $\begin{array}{l}\text { "Maintain the prevalent societal structures and patronize the } \\
\text { reigning communal ideology." }\end{array}$ \\
\hline \multicolumn{2}{|c|}{$\begin{array}{l}\text { e.g., social democratic ideology (Nordic countries) that are protectors of the remains of the welfare } \\
\text { of the state. }\end{array}$} \\
\hline $\begin{array}{l}\text { Reformative Particular } \\
\text { Ideology }\end{array}$ & $\begin{array}{l}\text { "Renovate the prevalent societal structures as well as the reigning } \\
\text { communal ideology." }\end{array}$ \\
\hline \multicolumn{2}{|c|}{ e.g., Neoliberal ideology that tries to reintroduce classical liberalism. } \\
\hline $\begin{array}{l}\text { Subversive } \\
\text { ideology }\end{array}$ & $\begin{array}{l}\text { "Pull down the existing societal structure and introduce a new } \\
\text { communal ideology." }\end{array}$ \\
\hline
\end{tabular}

In this sense, the concepts of left-wing and right-wing are complex to define. For this reason, the analysis will be delimited by Coppedge's (1997) view that proposed the broad concept of the left- and right-wing ideologies.

\subsection{Freedom of speech}

Freedom of speech is one of the essential rights in democratic countries. In Colombia, this right is contained in the $21^{\text {st }}$ article of the 1991's Political Colombian Constitution:

"Se garantiza a toda persona la libertad de expresar y difundir su pensamiento y opiniones, la de informar y recibir información veraz $e$ imparcial, y la de fundar medios masivos de comunicación. Estos son libres y tienen responsabilidad social. Se garantiza el derecho a la rectificación en condiciones de equidad. No habrá censura". (It is guaranteed to all the people the freedom of expressing and disseminating their thoughts and opinions, informing and receiving verified and impartial information, and establishing mass communication means. They (the people) are free and have social responsibility. It is guaranteed the right to rectification equitably conditions. There will not be censorship.) 
In this sense, unless the information is not verified or fake, the right to express ideas and opinions is defended by the constitution. Therefore, each person has the freedom of expressing what they desire to express. According to Cubides-Cardenas et al. (2020), the right of freedom of speech in Colombia has opened the opportunity to discuss other issues like the freedom of thought, freedom of information, freedom of no censorship, freedom of the press, and freedom of rectification. The following section defines the notion of self-censorship

\subsection{Self-censorship}

Recently, people in many Latin American countries have raised their voices against the governments' mismanagement and the dominant groups' ideas. As it was expected, many of those who have spoken out have been silent either from the organization they worked for or for moral reasons, they self-censor. Noelle-Neuman (1974) suggests that the justification for such behavior (self-censoring) is due to fear of isolation from a specific social group. Other factors are related to a threat, imposition, or ethics. Self-censorship also represents a menace for the press due to not only political but also economic pressure. If people cannot express what they want, then the freedom of speech would be inconclusive. No country is excluded from self-censorship, even the most democratic country experienced such issue; however, transitional countries are exposed to banning due to political pressure.

Despite the right to freedom of speech, people tend to avoid language or opinions that can be condemned by others. Self-censorship can be seen, somehow, as a personal choice because people are not obliged to speak (Görlach, 2019). Moreover, self-censorship is "one of the sociopsychological mechanisms that often obstructs a well-functioning democratic society" (BarTal, 2017: 41). This action "prevents free access to information, obstructs the freedom of expression, and harms free flow of information" (Ibid.). People are unable to create a real image of the society they live in and end up modifying, believing, and accepting the views of the dominant groups. Therefore, any contradictory opinion is banned or rejected. In this study, the concept of self-censorship is considered from the perspective of Bar-Tal (2017). The next section presents the methodology.

\section{Methodology}

This section provides information about the approaches used and the structure of the columns' analysis.

\subsection{Critical Discourse Analysis (CDA)}

CDA, as Van Dijk (2008) expresses, studies the "way social power abuse, dominance, and inequality are enacted, reproduced, and resisted by text and talk in the social and political context" (p. 352). In other words, it attempts to reveal the real meaning and the purpose of what has been said and how it is represented in society. CDA is characterized by (Van Dijk, 2008):

(1) Its focus on social problems and political issues.

(2) The critical analysis of social problems in a multidisciplinary manner. That is to say, the analysis can be carried out through the lenses of linguistics, psychology, sociology, etc.

(3) It not only describes the discourse structures but explains them.

(4) The relationship between power and dominance in society. The way it is enacted, confirmed, legitimated, reproduced, or challenged. 
Within this view of analysis, language use is divided into micro or macro levels of social order. At the macro level, the context is analyzed to evidence traits of power, dominance, or inequality and to describe the issue in a situated manner. At the micro, specific features of the language are analyzed such as topics and lexicon. Among the ways to analyze and bridge both levels, Van Dijk (2008) proposes four: Member-groups, Action-process, Context-social structure, and personal and social cognition. The present analysis is based on the personal and social cognition domain. In the next paragraph, the ideological structures and discourse strategies are presented.

\subsection{Ideological structures and discourse strategies}

Through the discursive structures and strategies, ideologies can be acquired, expressed, and reproduce in the discourse. Van Dijk (2006) contends that a discursive structure can mark an ideology. For example, the use of the pronoun We/Us that is used commonly used by people who desire to include themselves in s specific group. Unlike the use of They/Them that usually constitutes an opposite group. The grammatical structures are not perse markers of ideology. They are part of the speaker's communication systems. However, when these structures are situated in a specific context, they influence the discourse. For instance, the syntactic structures (subject-verb, subject-verb-object, object-verb-subject). In the sentences "the USA invades Iraq", "Iraq was invaded by USA" the interpretation may affect the real intention of the speaker/writer. Generally, in active-voice sentences, the agent is the performer of the action directly affect the receiver whereas, in passive-voice types, the agent receives the action, thus it may lose the actual meaning of the statement. Moreover, the figures of speech (metaphors, hyperbole, similes, euphemisms) are used to emphasize either positive or negative ideological meaning through a formal structure.

Van Dijk (2006) adds that the ideological discourse is organized by a general strategy that encompasses two parts: the positive self-presentation, and the negative presentation of the other. It generally emphasizes the positive things of Us and dismisses the negative ones of Us. On the contrary, it de-emphasizes the positive information about Them and emphasizes the negative ones. Consequently, it becomes a polarizing principle. Table 2 shows some of the ways the discourse ideologies are enacted at the macro level.

Table 2. Some expressions of ideologies in discourse

Context: Speaker speaks as a member of a social group; and/or addresses recipient as a group member; ideologically biased context models: subject representations of a communicative event and its participants as members of categories or groups.

Text, discourse, conversation:

Overall strategy: positive presentation/action of Us, negative presentation/action of Them

1. Emphasize Our good things, and Their bad things, and

2. De-emphasize Our bad things and Their good things.

Note: Adapted from Some expressions of ideologies in discourse. From "Ideology and Discourse Analysis" by Van Dijk, T. (2006) Journal of Political Ideologies, 11(2), 115-140.

Table 1 provides some variables to be used as a framework to analyze the way ideologies are enacted in the discourse of two opinion columns in order to identify their influence in the constraints of freedom of speech.

\subsection{Selection of units of analysis}

The units of analysis were selected based on the following moves of communication strategy that are called the "ideological square" (Van Dijk, 1998): 
(1) Express/emphasize information that is positive about Us.

(2) Express/emphasize information that is negative about Them.

(3) Suppress/de-emphasize information that is positive about Them.

(4) Suppress/de-emphasize information that is negative about Us.

These moves helped me to identify the strategies employed in both opinion columns for analysis. Before conducting the analysis, the descriptions of the columns ${ }^{1}$ are presented: "Dilema Ético" (Ethical Dilemma) and "A Margarita" (To Margarita). These columns are interesting because they involve two well-recognized figures in Colombia. The first column was written by Margarita Rosa de Francisco, who is a Colombian actress, singer, composer, presenter, and writer. From her background, it seems that Margarita belongs to a sphere of society that can be defined as high class. The second column was written by Luz Ángela Sarmiento, who is the director of the editorial house El Tiempo. She is Luis Carlos Sarmiento Ángulo's daughter, a Colombian banker, owner of Grupo AVAL, one of the largest bank conglomerates in Colombia. The topic of discussion starts when Margarita, as a columnist of El Tiempo, writes a column where expresses her ideas about the country's social crisis. In a statement of her column, she indirectly referred to Luis Carlos Sarmiento Ángulo and his influence over the decisions taken in the country as to the financial sector through Alvaro Uribe Vélez (a Colombian ex-president), Iván Duque's (president of Colombia) mentor. For this reason, Luz Ángela responds with the column, "A Margarita”. Luz Ángela shows her disagreement with Margarita's words and provides her point of view about the situation stated. In the following section, the analysis is presented.

\section{Analysis}

This section provides an analysis of the columns. The use of the expressions of ideology in discourse by Van Dijk (2006) is arranged in two different levels (Table 1): context, text, and discourse, and a critical analysis based on his 2008 CDA proposal. For the columns "Dilema Ético" and "A Margarita", four units of analysis were identified respectively. They were classified as follow (Table 3):

Table 3. Overall discourse strategy

\begin{tabular}{|l|c|c|}
\hline Discourse strategy & "Dilema Ético" & "A Margarita" \\
\hline positive presentation/action of Us & 0 & 1 \\
\hline Positive presentation of them & 0 & 1 \\
\hline negative presentation/action of Them & 4 & 3 \\
\hline
\end{tabular}

\subsection{Ideological analysis}

Tables 4 and 5 show the analysis of the columnist contexts. Table 6 and Table 7 describe the analysis of the units. The selection was based on the recurrence of the variables (Table 3 ) and the salience within the text. The macrostructure level involves the context and text, the microstructure level which addresses the meaning and form.

${ }^{1}$ Both columns are available on https://www.eltiempo.com/opinion/columnistas/margarita-rosa-defrancisco/dilema-etico-columna-de-margarita-rosa-de-francisco-566095. 
Table 4. Analysis of the context: "Dilema Ético"

\begin{tabular}{|l|l|}
\hline \multicolumn{2}{|c|}{ Margarita Rosa de Francisco's Column } \\
\hline \multicolumn{1}{|c|}{ Spanish } & \multicolumn{1}{c|}{ English } \\
\hline $\begin{array}{l}\text { Los ciudadanos hoy contemplamos con } \\
\text { desolación la misma barbarie, desigualdad y } \\
\text { miseria, ellas sí, muy bien administradas, pues }\end{array}$ & $\begin{array}{l}\text { The citizens today look with desolation at the } \\
\text { same barbarity, inequality, and misery, they are } \\
\text { han logrado mantenerlas estables por } \\
\text { vécadas, siempre en el más cruel de los niveles. } \\
\text { in keeping them stable for decades, always at the } \\
\text { cruelest of levels. }\end{array}$ \\
\hline $\begin{array}{l}\text { The columnist identified herself as a citizen. Despised those who have managed the country the } \\
\text { presidents), and she considered she was affected by those decisions taken. This can have a } \\
\text { reference to the right-wing parties that have ruled the country during its republican history so that } \\
\text { she identified herself on the opposite side of the political spectrum (the left-wing). }\end{array}$ \\
\hline
\end{tabular}

Table 5. Analysis of the context: "A Margarita"

\begin{tabular}{|l|l|}
\hline \multicolumn{2}{|c|}{ Luz Ángela Sarmiento } \\
\hline \multicolumn{1}{|c|}{ Spanish } & \multicolumn{1}{c|}{ English } \\
\hline Los términos de la columna de Margarita Rosa & The terms of the column of Margarita Rosa de \\
de Francisco son tan injuriosos contra Luis & Francisco are so insulting against Luis Carlos \\
Carlos Sarmiento Angulo, mi padre, y contra & Sarmiento Angulo, my father, and against this \\
este periódico que ameritan una reflexión. & newspaper that they deserve a reflection. \\
\hline Although the columnist does not explicitly provide the context, the word, my father, and, against \\
the newspaper, may have revealed her political position. Her father is a well-known banker in \\
Colombia, who is the newspaper owner, and that has been accused to influence the decisions of the \\
Colombian president (right-wing). Therefore, she may be aligned to such a political stance \\
\hline
\end{tabular}

Table 6. Text, discourse, and conversation

\begin{tabular}{|c|}
\hline $\begin{array}{c}\text { Text, discourse, and conversation } \\
\text { Column: "Dilema Ético" }\end{array}$ \\
Negative Presentation/ Action of them
\end{tabular}

(Example 1) El presidente más remoto en mi recuerdo es Misael Pastrana, y de ahí para adelante, todos los que le siguieron me han parecido uno solo. (The most remote president in my memory is Misael Pastrana, and from then on, everyone who followed him has seemed to me the same one).

The columnist mentioned the Colombian ex-president Misael Pastrana whose political inclination was aligned with the conservative party in Colombia (right-wing party). Then, she used the expressions "todos", "me han parecido uno solo", "ahí para adelante" which means that the most significant Colombian ruling government has been aligned with the right-wing. In other words, Colombian has been guided by politicians with right-wing ideas.

(Example 2) Aun cuando el último proceso de paz significó para muchos de nosotros un milagroso acontecimiento, este ocurrió dentro de un gobierno con los mismos vicios de todos los precedentes. (Even though the last peace process meant a miraculous event for many of us, it happened within a government with the same vices as all the previous ones.)

The columnist expresses that the peace process was positive for the country; however, she highlights that it happened under the rule of a government with the same vice. Therefore, she confirms what she said about the right-wing governments in the country.

(Example 3) ¿Cómo hacerme la desentendida cuando, todos los días -por vías alternativas-, periodistas de gran trayectoria y basados en investigaciones muy serias denuncian los alcances de la corrupción empresarial asociada con la política, las autoridades de justicia, el paramilitarismo y el narcotráfico? (How can I become disengaged when, every day, through alternative channels, journalists of great trajectory and based on very serious investigations denounce the extent of corporate corruption associated with politics, the justice authorities, paramilitarism and drug trafficking?)

The columnist utilized the expressions "investigaciones muy serias" and "denuncian" to validate her thoughts and accuse the government and the justice system. Then, she mentioned that those 
accusations are linked to corporate corruption, paramilitarism, and drug trafficking. In this stage, she associates these problematics with the previous governments' vices, and thus to the right-wing politicians

(Example 4) ¿Cómo no pensar en personas más innombrables que "el innombrable", dueños de todo el país, que financian las campañas de presidentes como el que hoy nos malgobierna? ¿Cómo no empezar a gritar que no es "el que diga Uribe", sino el que diga el más innombrable e intocable de todos, ese que alguna vez se ufanó de mandar a confeccionar leyes a su medida? (How not to think of people more unmentionable than "the unmentionable," owners of the whole country, who finance the campaigns of presidents like the one that is currently governing us? How can we not begin to shout that it is not "Uribe who says," but the most unspeakable and untouchable of all, the one who once boasted of having laws tailored to his needs?)

The columnist used the words "personas más innombrables", and "el innombrable" to refer to two recognized people in the country: Luis Carlos Sarmiento Angulo, and Alvaro Uribe Velez. The first is a banker and the second an ex-president that has a great influence on public opinion due to his questionable fight against the guerrilla during his mandate between 2002-2010. Therefore, he became a representative of the Colombian's right-wing parties along with the Conservative party. He also influenced the presidential elections in 2010 (ex-president Juan Manuel Santos which, under his mandate, the peace accord was signed) and 2018 (Iván Duque Marquez) whose candidates were elected. She expresses "dueños de todo el país que financian las campañas de los presidentes" that is interpreted as the elite, represented in this column by Luis Carlos Sarmiento Ángulo is who controls the decisions taken in the country. She also says "como el que hoy nos malgobierna" which means that the is ruled by the same model over the last 70 years.

It is evidenced that Margarita's column accuses the elite and right-wing parties to maintain the hegemony of the country. This has resulted in the social crisis the country faces. However, this view may be uncomfortable for Colombians who are aligned with right-wing ideologies either because they belong to the elite sphere or belong to the private corporates. Table 3 shows the analysis of Luz Ángela's column response. The table displays examples that start with the number 1 each time the unit under analysis changes.

Table 7. Text, discourse and conversation

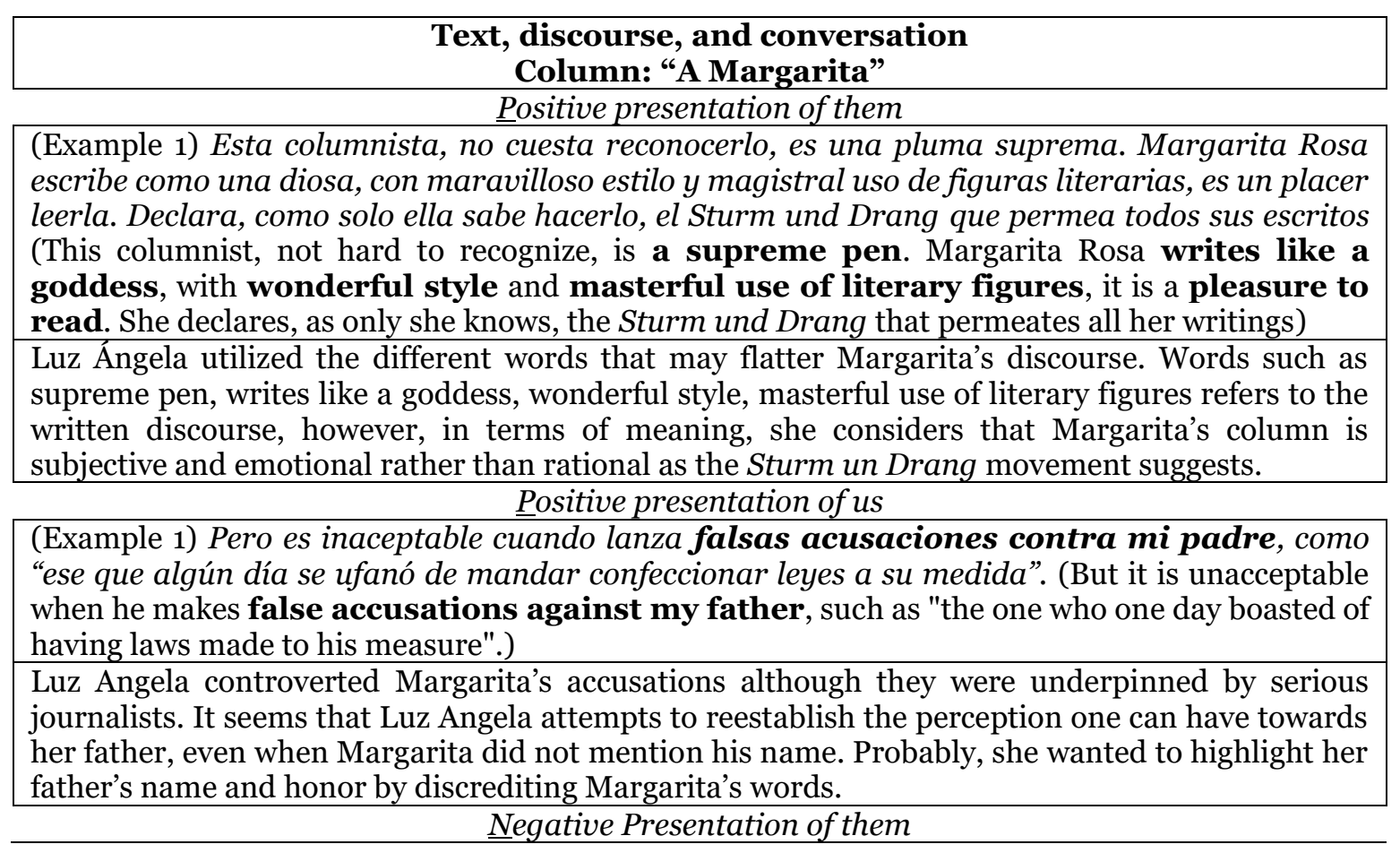


(Example 1) Se siente cínica ante toda forma de gobierno en este país desde los años 70 hasta nuestros días. (She feels cynical about any form of government in this country from the $1970 \mathrm{~s}$ to the present day.)

Luz Ángela said that Margarita feels cynical as to the governments in the country over past years. The word cynical may suggest that Luz Ángela wants to transmit that Margarita is not sincere and is driven by her own interest, thus she is not trustful.

(Example 2) Eso tristemente solo demuestra una gran ignorancia de los componentes del sistema bancario en Colombia, de sus regulaciones y funcionamiento. (That sadly only demonstrates a great ignorance of the components of the banking system in Colombia, of its regulations and functioning.)

The word ignorance denotes the lack of knowledge or understanding of something; however, its pejorative meaning may refer to uneducated. Luz Ángela used adverbs such as sadly and a great to intensify the meaning of the word, thus it may be understood that the word ignorance has a pejorative meaning.

(Example 3) Nuevamente, desconocimiento del sistema. Los clientes -ni los nuestros ni los de nadie- son prisioneros. (Again, ignorance of the system. Clients-neither ours nor anyone else'sare prisoners.)

The writer emphasized the word ignorance a second time. It probably shows that she discredited Margarita's accusations as to the Colombian bank system. This may reinforce the pejorative meaning of the word ignorance.

\subsection{Critical Discourse Analysis}

This section discusses the intended meaning enacted by both columnists and their positionality concerning two opposite ideologies: left-wing and right-wing ideas.

Margarita began her opinion column by describing the political context. She referred to Misael Pastrana, a Colombian ex-president who had been affiliated to the Colombian's Conservative party. Then, she mentions "me han parecido uno solo" (I found them similar) to refer to the continuity of the same set of ideologies that have ruled the country for decades. Later, she points out the peace process and highlights the meaningfulness for many Colombians who are in favor of it (generally those aligned with leftish ideologies); however, the government in which this peace accord was signed, was also aligned with the same ideology of previous governments. Regarding the peace process, the right-wing parties and the members did not support it, but instead, they rejected it. In this sense, even though the peace process was signed under the rightwing government, it had also irregularities and acts against the law. This process marked a detachment of ex-president Juan Manuel Santos from the ideals of the party led by Alvaro Uribe Vélez. Then, Margarita used the words "barbarie, desigualdad, y miseria" (barbarity, inequity, and misery) to describe the panorama of the country nowadays. This shed some light on the social problems that the country faces in terms of poverty, health, education, environment, justice, and unequal tax payment between natural people and legal entities. Most of these words are related to the leftish discourses that request equity and justice. Finally, she concluded the paragraph by underlining that such problems have been "muy bien administradas" (well-administered) to affirm that they have rooted in the country and are led by right-wing politicians.

In the second paragraph, she expressed that "poco a poco, he ido asomándome con más curiosidad" (little by little, I've been leaning out with curiosity). Her words denote that she has become interested to expand her view of the country's social problems. She used the words "indignación, horror, ganas de intervenir" (indignation, horror, and willingness to participate) to express her willingness to participate in the public discussion. She highlights that the social inequality and injustice enacted in the country were the triggering factors for her interest. She also has political interests as she supports the left-wing candidate for the 2021 presidential elections. Then, she mentioned that "opinar en contra de ciertos temas en un medio oficial" (provide an opinion about certain topics in an official newspaper), and "no recomendable" (no 
recommended) suggest that some means of communication and mass media are influenced by the ruling government so that an opinion against may be condemned. Moreover, she added that "cada vez me queda más dificil mirar para otro lado" (It's getting harder and harder for me to look the other way). Therefore, she feels that the 2021 presidential and parliamentary elections are crucial for the future of the country, thus she has to establish a position.

In the third paragraph, Margarita used rhetorical questions which relate to the articulation of the power in Colombia, and the severe complaints and investigations that wellrecognized journalists have evidenced in regards to the "corrupción empresarial asociada con la política, las autoridades de justiciar, el paramilitarismo, y el narcotráfico" (the corporate corruption associated with the polity, the justice, the paramilitarism, and the drug-traffic). She affirmed that there is a link between corporate corruption, and other problems, and the polity; however, she did not mention who, apart from right-wing politicians.

In the fourth paragraph, again, Margarita began with another rhetorical question. Here, she implicitly pointed out two different subjects when she says "personas más innombrables que 'el innombrable' dueños del país" "people more unmentionable than the unmentionable one". The first subject mentioned is Luis Carlos Sarmiento Angulo, one of the richest bankers in the country who is the owner of the largest bank conglomerates in the country Grupo AVAL, and the editorial house and newspaper EL Tiempo. On the other hand, "el innombrable" refers to the rightwing Colombian ex-president Alvaro Uribe Vélez who has influenced the politics since the 8os, especially during 2002 and 2008 when he was the president and the posterior governments that have been elected due to his support (Juan Manuel Santos and Iván Duque). This is confirmed when she affirmed, "el que diga Uribe" (the one Uribe says) which means that any presidential candidate he supports ends up elected. Those governments which she refers to as "nos malgobierna" (misgovern us), show her concern about the polity and the social reality of the country. Therefore, this person has a great influence on the decisions taken in the country.

In the last paragraph, Margarita expressed "hacer pequeños actos éticos" (to make small ethical acts) and "simbólicos" (symbolic) to influence the reader to act against the country's hegemony to maintain the "dignidad" (dignity). She concluded her column by stating "El mio es, por lo pronto, haber escrito esto" (Mine, so far, has been written this). It denotes a withdrawal from the newspaper due to the incompatibility of her own ideas, and the ideas of the newspaper. She felt her voice may be silent, thus she self-censored. The following section presents an analysis of the column "A Margarita".

Luz Ángela began by mentioning the opinion column Margarite wrote. She refers to Margarita's opinion as "términos injuriosos" (offensive terms). In other words, she affirms that such opinion is an infringement of his father's and the newspaper's honor. She places her father's honor as the topic of the discussion. It is relevant to notice here that her father is Luis Carlos Sarmiento Ángulo who has been accused of influence in Alvaro Uribe Vélez (right-wing figure) power over the current government. Hence, this is the link between Luz Ángela and the right-wing ideology.

In the second and third paragraph, Luz Ángela provided two examples of two former columnists, José Obdulio Gaviria, and Claudia López, that had been fired due to defamation and questioning the honor of, the first, the high commissioner of peace, and the second, the owners of the newspaper El Tiempo. However, the resignment in both cases occurred differently. José Obdulio Gaviria was allowed to continue in the newspaper while Claudia López was immediately fired. Both columnists have opposite ideals, the first connects better with the right-wing party whereas the second is on the left-wing. The situation that Claudia López lived in is similar to the one Margarita Rosa de Francisco experienced. Both questioned the influence and interests of the owners' newspaper in public opinion and the politics in the country. 
In the third paragraph, Luz Ángela referred back to Margarita's words "medio oficial" (official newspaper) "no recomendable" (no recommended). Luz Ángela then attributed a negative connotation to the words by defining them as "ideas de confabulaciones y amenazas" (ideas of collusion and threat). It seems that she tries to discredit Margarita's opinion. Then, she asked for "claridad y exactitud" (clarity and precision) of the intentions of the words after she has already devalued the statement.

In the fourth paragraph, Luz Ángela flattered Margarita by saying "pluma suprema, escribe como una diosa, con maravilloso estilo y magistral uso de figuras literarias, es un placer leerla" (supreme writing, she writes like a goddess, marvelous style and masterful use of literary figures). However, she added that "Declara, como solo ella, el Sturm und Drang que permea todos sus escritos" (She manifests, like only her, the Sturm und Drang that pervade all her writings). At first sight, it could read that Luz Ángela truly flatters Margarita; nevertheless, the following statement minimizes her attributives and condemn her ideas. The "Sturm und Drang" was a movement between the 6os and 8os. Emotions and subjectivity were expressed freely in opposition to the rationalism imposed by the enlightenment. In this sense, the attribution that Luz Ángela provides to Margarita's words is more on the emotional side rather than the rational. Then, Luz Ángela used the expression "se siente cínica" (she feels cynical) when she talks about the governments that have ruled the country over the last seventy years and added that "anuncia que quiere intervenir en la discusión pública" (she announces she wants to intervene in the public discussion). In other words, Margarita distrusts the former governments so that she feels she is entitled to participate in the public discussion.

In the fifth paragraph,laza Luz Ángela went back to the subject of her father's honor by expressing "lanza falsas acusaciones contra mi padre" (she utters false accusations against my father). She intends to reassure that her father had not been involved in any of the events that Margarita had mentioned. Even, Luz Ángela, once again, devalued Margarita's opinion by infantilize it and treat it as lacking a valid argument and ignorant of the components of the bank system, regulation, and functioning in the country. In other words, since Margarita does not know about the bank system, she should not discuss it.

In the last paragraphs, Luz Ángela addresses a situation that occurred in the country when, through the social media, some activists defy the bank conglomerate by asking Colombians to cancel their bank accounts due to the presumable links that Luis Carlos Sarmiento Ángulo, through the corporation Corficolombiana (A Colombian financial company), had with what it is known as the Odebrecht case. Luz Ángela affirmed that "eso nunca sucedio" (it never happened). She finishes her column by sending Margarita a message of censorship "las difamaciones vulgares no serán toleradas nunca en este periódico" (vulgar defamation won't be tolerated in this newspaper). In other words, Margarita had either to align with the newspaper's ideology or withdraw.

\section{Conclusion}

By using Van Dijk's ideological structures and discourse strategies, I identified and analyzed expressions used by two columnists that represent to political ideologies and how this can enact self-censorship. Moreover, I described the concept of ideology as a general term, and more specifically, to a political stance: the left- and right-wing concepts, freedom of speech, and self-censorship. The analysis was conducted through Van Dijk's (2008) CDA approach and his Ideological structures and discourse strategies example (Van Dijk, 2006). The findings showed that the columnist aligned with the right-wing ideology imposed on the columnist, who represented left-wing ideology, that was a causal of her withdrawal and that censorship. As for the methodology, CDA does not have a defined structure that can be of conflict by the moment of the analysis, thus identifying the units of analysis becomes a demanding process. Hence, it is essential 
to be familiar with different views of the concept of CDA. However, it is practical since it allows to study diverse subjects, situations, and materials (an opinion column, in the case of this study). For further research, it is suggested to analyze the discourse of other groups of media outlets in Colombia in order to be aware of their agenda-setting and their influence over individuals' opinions.

\section{Acknowledgements}

I would like to thank professors Alejandra Asomoza and Jorge Valladares for their patience and support during the process of the analysis of the discourse. I am grateful for the University of Guanajuato that has helped me to become a better professional.

This research did not receive any specific grant from funding agencies in the public commercial, or not-for-profit sectors.

The author declares no competing interests.

\section{References}

Bar-Tal, D. (2017). Self-censorship as a socio-political-psychological phenomenon: Conception and research. Advances in Political Psychology, 38(S1), 37-65. https://doi.org/10.1111/pops.12391

Boix, C. (1996.). Partidos políticos, instituciones domésticas y economía. In Boix, C. (Ed.), Partidos políticos, crecimiento e igualdad: estrategias económicas conservadoras y socialdemócratas en la economía mundial (pp. 345-379). Alianza.

Cañizález, A. (2015). Libertad de prensa y de expresión en los países andinos. Tensión, amenazas y restricciones. Intento de Balance 2013-2014. Temas de comunicación, (29), 49-111. http://revistasenlinea.saber.ucab.edu.ve/temas/index.php/temas/article/view/2240.

Coppedge, M. (1997). A classification of Latin American political parties. Working Paper, 244. https://kellogg.nd.edu/documents/1539.

Cubides-Cárdenas, J., Navas-Camargo, F., Ortiz-Torres, D., \& Fajardo, A. (2020). La libertad de expresión en Colombia: Parámetros constitucionales y reglas jurisprudenciales. Directos Sociais $e$ Políticas Públicas, 8(2), 500-562. http://dx.doi.org/10.25245/rdspp.v8i2.834

Fagerholm, A. (2016). Ideology: A proposal for a conceptual typology. Social Science Information, 55(2), 137-16o. https://doi.org/10.1177/0539018416629229

Gerring, J. (1997). Ideology: A definitional analysis. Political Research Quarterly, 50(4), 957-994. https://doi.org/10.2307/448995

Gómez, J., \& Hernández, J. (2008). Libertad de prensa en Colombia: la contradicción en la búsqueda de la verdad. Palabra Clave, 11(1),109-122. https://palabraclave.unisabana.edu.co/index.php/palabraclave/article/view/1421.

González, L. E., \& Queirolo, R. (2013). Izquierda y derecha: formas de definirlas, el caso latinoamericano y sus implicaciones. América Latina Hoy, 65(1), 79-105. https://doi.org/10.14201/alh20136579105

Görlach, A. (2019, May 30). Language between self-censorship and political correctness. Deutsche Welle. https://www.dw.com/en/opinion-language-between-self-censorship-and-politicalcorrectness/a-48974813. 
Noelle-Neumann, E. (1974). The spiral of silence: A theory of public opinion. Journal of Communication, 24, 43-51. https://doi.org/10.1111/j.1460-2466.1974.tbo0367.x

Sartori, G (1991). Comparing and miscomparing. Journal of Theoretical Politics, 3(3), 243-257. https://doi.org/10.1177/0951692891003003001

Van Dijk, T. (1998). Ideology: A multidisciplinary approach. SAGE.

Van Dijk, T. (2008). Critical discourse analysis. In Schiffrin, D., Tannen, D., \& Hamilton, D. (Eds.). The handbook of discourse analysis (pp. 352-371). Wiley.

Van Dijk, T. (2006). Ideology and discourse analysis. Utopía y Praxis Latinoamericana, 10(9), 9-36. http://www.redalyc.org/articulo.oa?id=27910292. 
J. A. Marín González - Discourses of ideologies and freedom of speech

C O A $\mathrm{s}$ 